\title{
GENETIC AND ECONOMIC ANALYSIS FOR THE RELATIONSHIP BETWEEN UDDER HEALTH AND MILK PRODUCTION TRAITS IN FRIESIAN COWS
}

El-Awady, H. G. ${ }^{*}$ and E. Z. M. Oudah ${ }^{\star *}$

*Animal Production Dept., Fac. of Agric., Kafrelsheikh Univ., PC: 33516, Kafrelsheikh, Egypt, E-mail: hassanelawady@yahoo.com

${ }^{\star *}$ Dept. of Animal Production, Fac. of Agric., Mansoura Univ., PC: 35516, Mansoura, Egypt, E-mail: eoudah@uoguelph.ca

\begin{abstract}
A total of 4752 monthly lactation records of Friesian cows during the period from 2000 to 2005 were used in the present study. Three milk production traits were studied: 305-day milk yield (305-dMY), 305-day fat yield (305-dFY) and 305-day protein yield (305-dPY). Four udder health traits were studied: somatic cell count (SCC), mastitis (MAST), udder health status (UDHS) with 11 categories and udder quarter infection (UDQI) with 8 categories. Mixed model least square analysis was used to estimate the fixed effects of month and year of calving and parity $(P)$ on different studied traits. Sire and dam within sire were included in the model as random effects. Data were analyzed using Multi-trait Derivative Free Restricted Maximum Likelihood methodology (MTDFREML) to estimate genetic parameters. Unadjusted means of 305-dMY, 305-dFY, 305-dPY and SCC were 3936, 121, $90 \mathrm{~kg}$ and 453,000 cells $/ \mathrm{ml}$, respectively. Increasing SCC from 300,000 to 2000,000 cells/ml increased UDQI from 5.51 to $23.2 \%$. Losses in monthly and lactationally milk yields per cow ranged from 17 to 93 and from 135 to $991 \mathrm{~kg}$, respectively. The corresponding losses in monthly and lactationally milk yields return per cow at the same level of SCC ranged from 29.8 to 163 and from 236 to 1734 Egyptian pounds, respectively. Heritability estimates of 305-dMY, 305-dFY, 305-dPY, SCC, MAST, UDHS and UDQI were $0.31,0.33,0.35,0.23,0.14,0.13$, and 0.09 , respectively. All milk production traits showed slightly unfavorable negative phenotypic and genetic correlations with SCC, MAST, UDHS and UDQI. There were positive and high genetic correlations between SCC and each of MAST (0.85), UDHS (0.87) and UDQI (0.77) and between MAST and each of UDHS (0.91) and UDQI (0.83). It could be concluded that the economic losses from mastitis and high SCC are considerable. The high genetic correlation between SCC and clinical mastitis (CM) makes SCC a feasible indicator for CM. It recommended also that if direct information on under health traits is not available, measures of SCC can be used indirectly to improve these traits genetically. Keywords: somatic cell count, udder health, mastitis, genetic parameters, economic losses
\end{abstract}

\section{INTRODUCTION}

The udder is one of the most important physiological and conformational characteristics of the cow (White and Vinson, 1975) due to its importance for milk production. Consequently, udder health is generally considered as one of the most important traits in dairy cattle production (Miglior et al., 2005). Mastitis has been recognized as a major disease affecting dairy cattle and jeopardizing milk production and quality in commercial herds especially in its sub-clinical form (Schepers and Dijkhuizen, 
1991; De Graves and Fetrow, 1993 and Losinger, 2005). Non-management factors such as season, parity, lactation stage, breed, udder conformation, milk production, milking speed and reproductive disorders are known to be associated with mastitis (Schukken et al., 1990; De Graafa and Dwingerb,1996; Barkema et al., 1998; Hagnestam et al., 2007, Nyman, 2007 and Dürr et al., 2008). Hultgren and Svensson (2009) found that ninety percent of the variation in mastitis risk was due to factors at the lactation level such as parity, milk yield, cow diseases, and other disturbances. In addition to the factors mentioned above, the genetic constitution and innate immune defense of a cow plays an important role in determining disease resistance in individual cows. Shook (1989) pointed out that there are several anatomical, physiological and immunological defense mechanisms in the cow against mastitis, and a large number of genes operate in these defenses. Also, nutrition can influence the cow's resistance to mastitis (O'Rourke, 2009).

Profitability of a dairy herd is a function of revenues and costs. Udder health affects both revenues and costs. Bovine mastitis remains a major cause of economic losses in dairy herds and the industry (Petzer et al., 2009) and it is still one of the three main diseases that affect the profitability of dairy farmers - lameness and fertility are the other two (O'Rourke, 2009). Costs related to mastitis are extensive. Economic losses from mastitis are considerable and result from reduced milk yield, discarded milk, reduction in milk price because of high SCC, veterinary and treatment costs, increased labor, and increased culling rate (Bartlett et al., 1990). Seegers et al. (2003) found that the total reduction in milk production resulting from clinical mastitis (CM) was around $375 \mathrm{~kg} \mathrm{(5 \%} \mathrm{at} \mathrm{the} \mathrm{lactation} \mathrm{level).} \mathrm{Production} \mathrm{losses} \mathrm{are,}$ however, very variable and substantially influenced by, for instance, when in lactation the cow become diseased. Hagnestam et al. (2007) estimated a reduction in 305-day milk production between $0-902 \mathrm{~kg}(11 \%)$ depending on parity and the week of lactation at clinical onset. Results of Blosser (1979) also showed that losses of milk yields caused by mastitis were $386 \mathrm{~kg} / \mathrm{cow}$ per year and losses of discarded milk $62 \mathrm{~kg} / \mathrm{cow}$ per year. Hultgren and Svensson (2009) found that the total mean costs of veterinary-reported clinical mastitis (VRCM) were estimated to be $\$ 735$ per lactation with a diagnosis of CM, $\$ 103$ per lactation across all cows, or $\$ 95$ per cow annually during lifetime. Hagnestam-Nielsena and Østergaarda (2009) found that the cost (expressed per cow-year) per case of $\mathrm{CM}$ was estimated at $€ 428$. Estimates of the cost per case of $\mathrm{CM}$ vary depending on sources of economic loss included, data and estimation method, and can therefore not be easily compared. Apart from production losses, mastitis-related involuntary culling involves considerable costs.

In recent years, genetic evaluation for mastitis resistance has received increasing attention in dairy cattle breeding. Somatic cell count has several desirable attributes as an indicator trait for $\mathrm{CM}$, and its use for this purpose is therefore widespread (Interbull, 2008). They are also readily available at a low additional cost in most milk-recording schemes, and they reflect both clinical and subclinical mastitis (Philipsson et al., 1995; Mrode and Swanson, 1996 and Heringstad et al., 2000). Somatic cell count also is generally used for identifying cows with subclinical mastitis, a change in SCC 
from under to over a threshold of 200,000 cells per $\mathrm{ml}$ has been reported to be a predictor of intramammary infection (Dohoo and Leslie, 1991; Schepers et al., 1997). From the genetic point of view, the heritability of clinical mastitis is low, especially when analyzed with linear models (Pösö and Mäntysaari, 1996; Rupp and Boichard, 1999; Lassen et al., 2003). Owing to the higher heritability of SCC and its high genetic correlation with clinical mastitis, it can be used for indirect selection to improve mastitis resistance (Mrode and Swanson, 1996; Heringstad et al., 2000). Previous studies (e.g. Mrode and Swanson, 1996) reported heritability estimates of 0.11 to 0.15 for SCC in the Holstein-Friesian breed, suggesting that SCC is under modest genetic control. However, selection has been proven to be most efficient when information on clinical cases and SCC are combined (Philipsson et al., 1995).

The aims of this study were to evaluate the genetic and phenotypic relationship between milk production traits and udder health traits, estimation of genetic parameters for these traits and estimation of the economic milk losses due to bad udder health traits in Friesian cattle raised in a governmental farm in Egypt.

\section{MATERIALS AND METHODS}

\section{Data and management}

Data on monthly lactation records of Friesian cows belonging to Sakha Animal Production Research Station, Animal Production Research Institute, Ministry of Agriculture situated at Kafrelsheikh Governorate in the northern part of Nile Delta of Egypt. The initial number of records used in the present study was 7450 monthly lactation records involved 784 Friesian cows sired by 89 sires. Because of excluding some incomplete records and traits limitation, the final total number of records used in the statistical analyses was 4752 of 439 Friesian cows sired by 52 sires during the period from 2000 to 2005.

Cows were artificially inseminated at random. Heifers were serviced for the first time when reached 18 months of age or $350 \mathrm{~kg}$ live body weight which come first. Cows were usually serviced two months postpartum. Pregnancy was detected by rectal palpation 60 days after last mating. The cows were loosely housed in open sheds system. Cows were kept under similar system of feeding and management practiced on the farm applied by APRI . All cows were fed on good quality concentrate ration. During winter and spring months (from December to May), animals were supplied with Egyptian clover (Trifolium alexandrinum), while during summer and autumn (from June to November), animals were fed on dry ration, mainly either Egyptian cover hay or green sweet sorghum. Also, rice straw was available around the year. Feeds were supplied to cows according to their live body weight, milk production and pregnancy status. Portable water and mineral mixture were available freely. Cows were machines milked twice daily in a parallel. Milk yield was recorded daily to the nearest $100 \mathrm{~g}$ at each milking. Cows were usually dry off about two months before the expected calving date. 


\section{Analyzed traits : \\ Milk production traits:}

Monthly milk production records were available for each cow. The averages of daily milk yield, monthly milk yield and 305-dday milk yield were calculated. Daily milk yield calculated as the 305-day milk yield divided by days in milk. Milk samples were taken weekly from each cow for chemical analysis of the milk constituents which include: percentages of fat, protein, lactose, total solids and solid non-fat (SNF). The following milk production traits were studied: 305-day milk yield (305-dMY, Kg), 305-day fat yield (305$\mathrm{dFY}, \mathrm{kg}$ ) and 305-day protein yield (305-dPY, kg)

\section{Udder health traits:}

1. Somatic cell count (SCC): The SCC was measured by a Fossomatic Cell counter from a sample of the milk collected during the morning milking. The determination of SCC (by thousand cells per millimeter milk) was performed at Dairy Service Unit belonging to APRI, Sakha, Kafrelsheikh Governorate. Somatic cell count was calculated as the lactation-average of the arithmetic mean of the monthly SCC from calving to the end of lactation in 1000 cells $/ \mathrm{ml}$ milk. The SCC was classified into 12 categories $(\leq 50,>50-100,>100-200$, $>200-300,>300-400,>400-500,>500-600$. >600-700. $>700-800,>800-1000$, $>1000-2000,>2000$ thousand cells $/ \mathrm{ml} \mathrm{milk}$.

2. Mastitis (MAST): a binary trait measured as incidence of clinical mastitis. A case of mastitis was the veterinary treated clinical mastitis during the period from calving to the end of lactation period. For clinical mastitis condition, an indicator variable represented the occurrence or absence of the disease $(1=$ occurrence; 0 = absence).

3. Udder health status (UDHS): Udder health status classified into 11 categories from 0 to 10 as follows: $0=$ normal, $1=$ bloody milk, $2=$ coagulated milk, $3=$ mastitis, $4=$ inguinal and mammillitis, $5=$ surgical cut, $6=$ traumatic inflammation and abrasions, 7 = chromatic mastitis, $8=$ coagulated milk and teat paralysis, $9=$ teat claw and $10=$ purulent in udder.

4. Udder quarter infection (UDQI): Udder quarters were considered to be infected when the SCC are $\geq 400,000$ cells $/ \mathrm{ml}$ milk or when cluster pathogens results were positive from consecutive milk samples. Udder quarters were classified into 8 categories from 0 to 7 as follows: $0=$ normal, $1=$ right fore quarter infection, $2=$ left fore quarter infection, $3=$ right hind quarter infection, $4=$ left hind quarter infection, $5=$ two quarters infection, $6=$ three quarters infections and $7=$ all quarters infections.

\section{Economic losses:}

The economic losses due to increasing SCC or quarter infection were measured by losses in milk returns comparing with the normal animals. The following equation was used: Milk returns $=$ selling price of one $\mathrm{kg}$ milk $\mathrm{x}$ milk production losses, where selling price of one $\mathrm{kg}$ of milk equal $1.75 \mathrm{EGP}$ according to the estimation of Animal Husbandry Section at Sakha Farm (the price according to the year 2008). 


\section{Statistical analysis: \\ Fixed effects:}

Least squares means and analysis of variance of environmental effects on studied traits were estimated by using least squares analyses of variance by Mixed Model program of Harvey (1990). Data set 1 were analyzed to estimate the effects of month and year of calving and parity $(P)$, on different traits studied as fixed effects and sire of the cow and dam within sire as random effects. The following mixed model (1) was used:

Where:

$$
Y_{i j k l m n}=\mu+S_{i}+D_{i j}+M_{k}+Y_{1}+P_{m}+e_{i j k l m n} \ldots \ldots \text { (1) }
$$

$$
\begin{aligned}
& Y_{i j k l m n}=\text { an observation of a trait on the i'th sire of the j'th dam nested } \\
& \text { within i'th sire of the k'th month of calving of the l'th year of } \\
& \text { calving and of the m'th parity, } \\
& \mu=\text { Overall mean, } \\
& \mathrm{Si}=\text { random effect of } \mathrm{ith}^{\text {th }} \text { sire, } \\
& D_{i j}=\text { random effect of } j^{\text {th }} \text { cow nested within } \mathrm{i}^{\text {th }} \text { sire, } \\
& M_{k}=\text { fixed effect of } k^{\text {th }} \text { month of calving }(k=1,2, \ldots \text { and } 12) \\
& 1=\text { January, } 2 \text { = February, } \ldots \text { and } 12=\text { December, } \\
& Y_{I}=\text { fixed effect of } I^{\text {th }} \text { year of calving }(I=1,2, \ldots . . \text { and } 6) 1=2000 \text {, } \\
& 2=2001, \ldots . \text { and } 6=2005) \text {, } \\
& P_{m}=\text { fixed effect of } m^{\text {th }} \text { parity }(m=1 \text { to } 5) \text {, and } \\
& \mathrm{e}_{\mathrm{ijk} \mid \mathrm{mn}}=\text { random error variance. }
\end{aligned}
$$

Data set 2 were analyzed to estimate the effect of SCC, UDHS and UDQI on losses in milk production traits as well as the relationship between SCC and each of UDHS and UDQI. The following mixed model (2) was used:

Where:

$$
Y_{i j k l m n o}=\mu+S_{i}+D_{i j}+M_{k}+Y_{1}+P_{m}+X_{n}+e_{i j k l m n o}
$$

$X_{n}=$ the fixed effect of SCC, UDHS or UDQI and the other symbols as defined in the model (1).

\section{Estimation of genetic parameters:}

Data were analyzed by animal model using multiple-trait derivativefree restricted maximum likelihood (MTDFREML) suite of programs (Boldman et al., 1995) To estimate the (co)variance components, heritability and genetic and phenotypic correlations for different studied traits. Analysis of variance showed that all milk production traits and SCC affected significantly $(\mathrm{P}<0.01$ or 0.05$)$ by month and year of calving and parity except the effect of month of calving on each of 305-dFY and 305-dPY was not significant. Therefore the model included month and year of calving and parity as fixed effects and effects of animal and residual as random effects. In multiple traits, the following general animal model used was:

$$
\mathbf{Y}=\mathbf{X} \boldsymbol{\beta}+\mathrm{Za}+\mathbf{e}
$$

Where: $Y=$ observations vector of records, $\beta=$ the vector of fixed effects, $a=$ the vector of direct genetic effects and $e=$ the vector of residual 
effects. $X$ and $Z$ are incidence matrices relating records to fixed and direct genetic, respectively. Estimates of additive direct heritability $\left(h^{2} a\right)$ were calculated as follows:

$$
h^{2} a=\sigma^{2} a /\left(\sigma^{2} a+\sigma^{2} e\right)
$$

Where: $\sigma^{2}$ is the additive direct genetic variance, $\sigma^{2} \mathrm{e}$ is the random residual effect associated with each observation.

(Co)variance components were calculated by Restricted Maximum Likelihood employing a simplex algorithm to search for variance components to minimize -2log likelihood (L). Convergence was assumed when the variance of the function values $(-2 \log L)$ of the simplex was less than $10^{-9}$. After the convergence, a restart was performed to verify that it was not a local minimum. Restarts were performed for all analyses, using the final results of the previous analysis, in order to locate the global maximum for the log likelihoods. Starting values for variance components for multi-trait analyses were obtained from literature.

\section{RESULTS AND DISCUSSION}

\section{Descriptive Statistics}

Unadjusted mean, standard deviation (SD) and coefficient of variation (CV\%) for milk production traits and SCC across lactations are present in Table 1. Overall unadjusted means of 305-day milk yield, 305-day fat yield, 305-day protein yield and somatic cell count across lactations were $3936 \pm 1044,121 \pm 54.3,90 \pm 38.0 \mathrm{~kg}$ and $453 \pm 218$ thousand cell $/ \mathrm{ml}$. The coefficients of variation for the same traits were $26.6,44.8,42.2$ and $48.1 \%$, respectively. Nearly similar results were found by El-Arian and El-Awady (2008) who working on 4015 records of Friesian cattle in Egypt. They found that the overall means $( \pm S D)$ of 305-day milk yield, 305-day fat yield, 305day protein yield and somatic cell count during the $1^{\text {st }}$ three lactations were $4038 \pm 1253,138 \pm 49.2,102 \pm 40.0 \mathrm{~kg}$ and $426 \pm 212$ thousand cell $/ \mathrm{ml}$. Also, Laevens et al. (1997) found that least squares mean the $\log _{\mathrm{e}}$-transformed $\left(\mathrm{x} 10^{3} \mathrm{cells} / \mathrm{ml}\right)$ SCC (InSCC) for first, second, and third parity cows were $3.80,3.93$, and 3.97 , respectively.

Table 1: Unadjusted mean, standard deviation (SD) and coefficient of variation for 305-day milk yield, 305-day fat yield, 305-day protein yield and somatic cell count.

\begin{tabular}{|l|c|c|c|}
\hline Trait & Mean & SD & CV\% \\
\hline 305-dMY, kg & 3936 & 1044 & 26.6 \\
\hline 305-dFY, kg & 121 & 54.3 & 44.8 \\
\hline 305-dPY, kg & 90 & 38 & 42.2 \\
\hline SCC, $\left(\mathbf{x} \mathbf{1 0}^{\mathbf{3}}\right.$ cells/ml) & 453 & 218 & 48.1 \\
\hline
\end{tabular}

\section{Effect of UDHS on milk production traits}

Table 2 shows the effect of UDHS on milk production traits. From this table it could be noticed that generally, most studied milk production traits affected negatively, with different levels, with UDHS classes (1 to 9 classes) 
compared with the normal udder ( 0 class). It could be noticed also from Table 2 that $85.1 \%$ of observations in this herd (4045 records from 4752) had normal udder ( 0 class). Clinical mastitis represents the highest percentage of UDHS defects (class number 3 ) with $10.2 \%$ of all observations. Meanwhile, the other eight classes (excluding normal udder and clinical mastitis) represent $4.7 \%$ of all observations. The highest losses in milk production traits were with chronic mastitis treatment (class No. 7) where the highest negative least square constants $(-570 \mathrm{~kg}$ for $305-\mathrm{dMY},-9.96 \mathrm{~kg}$ for $305-\mathrm{dFY}$ and $-9.19 \mathrm{~kg}$ for $305-\mathrm{dPY}$ ) followed by clinical mastitis (class No. 3) where the $2^{\text {nd }}$ rank of the negative least squares constants $(-193 \mathrm{~kg}$ for $305-\mathrm{dMY},-5.49$ $\mathrm{kg}$ for $305-\mathrm{dFY}$ and $-3.45 \mathrm{~kg}$ for $305-\mathrm{dPY}$ ) compared with the other UDHS defects. Seegers et al. (2003) found that the total reduction in milk production resulting from clinical mastitis was around $375 \mathrm{~kg}(5 \%$ at the lactation level). Production losses are, however, very variable and substantially influenced by, for instance, when in lactation the cow become diseased. Hagnestam et al. (2007) estimated a reduction in 305-day milk production between $0-902 \mathrm{~kg}(11 \%)$ depending on parity and the week of lactation at clinical onset. Losses of milk yields caused by mastitis were 386 $\mathrm{kg} /$ cow per year and losses of discarded milk $62 \mathrm{~kg} / \mathrm{cow}$ per year (Blosser, 1979).

Table 2: Least squares constant \pm standard error (SE) for 305-dMY, 305dFY and $305-\mathrm{dPY}(\mathrm{kg})$ as affected by udder health status classes

\begin{tabular}{|c|c|c|c|c|c|}
\hline \multirow[t]{2}{*}{ Effect } & \multicolumn{2}{|c|}{ Observation } & \multicolumn{3}{|c|}{ Constant estimates \pm SE } \\
\hline & No. & $\%$ & 305-dMY & 305-dFY & 305-dPY \\
\hline Constant & 4752 & 100 & $3204 \pm 91$ & $117 \pm 5.0$ & $91 \pm 3.94$ \\
\hline \multicolumn{6}{|c|}{ UDHS classes* } \\
\hline 0 & 4045 & 85.1 & $1383 \pm 92$ & $24.8 \pm 5.49$ & $17.8 \pm 3.43$ \\
\hline 1 & 59 & 1.24 & $-26 \pm 19$ & $-0.06 \pm 2.01$ & $1.19 \pm 1.00$ \\
\hline 2 & 39 & 0.82 & $-131 \pm 71$ & $-2.61 \pm 1.77$ & $-1.73 \pm 1.03$ \\
\hline 3 & 484 & 10.2 & $-193 \pm 99$ & $-5.49 \pm 2.09$ & $-3.45 \pm 1.76$ \\
\hline 4 & 35 & 0.74 & $-88 \pm 78$ & $-3.96 \pm 1.99$ & $-2.45 \pm 1.89$ \\
\hline 5 & 12 & 0.25 & $-28 \pm 27$ & $0.48 \pm 0.27$ & $0.70 \pm 1.00$ \\
\hline 6 & 19 & 0.40 & $-65 \pm 61$ & $1.63 \pm 1.06$ & $0.93 \pm 1.04$ \\
\hline 7 & 46 & 0.97 & $-570 \pm 161$ & -9.965 .11 & $-9.19 \pm 3.69$ \\
\hline 8 & 3 & 0.06 & $-93 \pm 63$ & -1.730 .99 & $-1.01 \pm 0.77$ \\
\hline 9 & 4 & 0.08 & $-123 \pm 81$ & -2.021 .20 & $-1.89 \pm 1.11$ \\
\hline 10 & 6 & 0.13 & $-66 \pm 32$ & -0.570 .47 & $-0.92 \pm 0.34$ \\
\hline
\end{tabular}

* $0=$ normal, $1=$ bloody milk, $2=$ coagulated milk, $3=$ clinical mastitis, $4=$ inguinal and mammillitis, $5=$ surgical cut in udder or teat, $6=$ traumatic inflammation and abrasions, $7=$ chronic clinical mastitis, $8=$ coagulated milk and teat paralysis, $9=$ teat claw and $10=$ purulent in udder.

\section{Effect of UDQI on milk production traits}

Table 3 shows the effect of UDQI on milk production traits. The majority of observations (85.1\%) were with normal udder ( 0 class) as reported before (Table 2). The percentages of udders with one quarter infected were 0.84 and $0.95 \%$ for right and left fore quarters (classes 1 and 2), respectively and 2.02 and $3.14 \%$ for right and left hind quarters(classes 3 and 4), respectively. The percentages of observations with two quarters and three quarters infected (classes 5 and 6 ) were 1.75 and $0.74 \%$, respectively. 
Finally, the percentage of observations with all udder quarters infected (4 quarters) was $5.45 \%$ which represents the highest percentage of udder quarters infections. The percentage udders with hind quarter's infections was higher than that with fore quarters infections (5.16 vs $1.79 \%$ for the hind and fore quarters infections, respectively). Generally, negative least squares constants were found associated with all classes of UDQI from 1-7 (with exception of 0 class with normal udders). Losses in 305-dMY from hind quarters (least squares constants -134 and -183 for the right and left quarters, respectively) were higher than that from fore quarters (least squares constants -19 and -14 , for the right and left quarters, respectively). The same trend was followed also for 305-dFY and 305-dPY. The differences in 305$\mathrm{dMY}$ losses between fore and hind quarter infections reflects unbalanced udder regarding the equal udder quarters. Least squares means for effect of UDHS on milk production traits showed that losses in 305-dMY, 305-dFY and 305-dPY for all udder quarters infections (4 quarters) were $-427,-8.55$ and $10.41 \mathrm{~kg}$, respectively (Table 3). Jackson (1996) mentioned that any injury or infection involving the skin of the teat is a potential threat to its efficient function and to the welfare of the animal. The sources of injury may be barbed wire, sharp objects and damaged or inadequate fencing. Wilson et al. (1971) reported that in dual-purpose cows means for log SCC were lower for front than for rear quarters, although differences between left front and left rear quarters were not significant. Failure to partially or completely empty a quarter would tend to increase the cell count of the milk. Nooruddin et al. (1997) showed that teat traits have an influence on mastitis, but the effect on milk yield is apparently not as significant as for intramammary infections. De Graafa, and Dwingerb (1996) found that no significant difference in milk production loss was detected when the data were stratified on the number of quarters affected.

Table 3: least squares constant \pm standard error (SE) for 305-dMY, 305$\mathrm{dFY}$ and $305-\mathrm{dPY}(\mathrm{kg})$ as affected by udder quarter infection classes (UDQI).

\begin{tabular}{|l|c|c|c|c|c|}
\hline \multirow{2}{*}{ Effect } & \multicolumn{2}{|c|}{ Observation } & \multicolumn{3}{|c|}{ Constant estimates \pm SE } \\
\cline { 2 - 6 } & No. & $\%$ & $305-d M Y$ & $305-d F Y$ & $305-d P Y$ \\
\hline Constant & 4752 & 100 & $3209 \pm 94$ & $116 \pm 3.00$ & $89 \pm 3.00$ \\
\hline \multicolumn{5}{|l|}{} \\
\hline $\mathbf{0}$ & 4045 & 85.1 & $1257 \pm 244$ & $22.71 \pm 7.49$ & $18.48 \pm 3.93$ \\
\hline $\mathbf{1}$ & 40 & 0.84 & $-19 \pm 14$ & $-0.49 \pm 0.01$ & $-0.19 \pm 0.27$ \\
\hline $\mathbf{2}$ & 45 & 0.95 & $-14 \pm 11$ & $0.00 \pm 0.07$ & $0.63 \pm 0.44$ \\
\hline $\mathbf{3}$ & 96 & 2.02 & $-134 \pm 99$ & $-2.67 \pm 1.29$ & $-0.81 \pm 0.76$ \\
\hline $\mathbf{4}$ & 149 & 3.14 & $-183 \pm 105$ & $-3.02 \pm 1.88$ & $-1.81 \pm 1.59$ \\
\hline $\mathbf{5}$ & 83 & 1.75 & $-218 \pm 144$ & $-3.19 \pm 2.27$ & $-2.16 \pm 2.07$ \\
\hline $\mathbf{6}$ & 35 & 0.74 & $-262 \pm 137$ & $-4.79 \pm 2.06$ & $-3.73 \pm 2.13$ \\
\hline $\mathbf{7}$ & 259 & 5.45 & $-427 \pm 183$ & $-8.55 \pm 4.96$ & $-10.41 \pm 4.79$ \\
\hline
\end{tabular}

${ }^{*} \mathbf{0}=$ normal, $1=$ right fore quarter infection, $2=$ left fore quarter infection, $3=$ right hind quarter infection, 4= left hind quarter infection, 5= two quarters infection, $6=$ three quarters infections and $7=$ all quarters infections.

\section{Relationship between UDHS and SCC}

Least squares constants for SCC as affected by UDHS classes are given in Table 4 . The chronic clinical mastitis ( $7^{\text {th }}$ class, $1.85 \%$ of 
observations) had the highest least square constant (+193,000 cell/ml). Clinical mastitis (3 ${ }^{\text {rd }}$ class, $8.49 \%$ of observations) came in the second rank after chronic clinical mastitis regarding the number of SCC in milk where least squares constant was $+133,000 \mathrm{cell} / \mathrm{ml}$. This result explains the high positive and significant genetic $(0.85)$ and phenotypic (0.69) correlations between mastitis and SCC (Table 10).

Table 4: Least squares constant \pm standard error (SE) for SCC as affected by udder health status classes (UDHS)

\begin{tabular}{|l|c|c|c|}
\hline \multirow{2}{*}{ Effect } & \multicolumn{2}{|c|}{ Observation } & SCC (x10 $\mathbf{3} / \mathbf{m l})$ \\
\cline { 2 - 4 } & No. & $\%$ & Constant estimates \pm SE \\
\hline Constant $^{*} 4712$ & 100 & $592 \pm 124$ \\
\hline $\mathbf{0 D H S}$ classes $^{*}$ & & & $-542 \pm 118$ \\
\hline $\mathbf{1}$ & 4005 & 85.0 & $18 \pm 13$ \\
\hline $\mathbf{2}$ & 57 & 1.21 & $86 \pm 41$ \\
\hline $\mathbf{3}$ & 55 & 1.17 & $113 \pm 83$ \\
\hline $\mathbf{4}$ & 400 & 8.49 & $52 \pm 31$ \\
\hline $\mathbf{5}$ & 46 & 0.98 & $-144 \pm 81$ \\
\hline $\mathbf{6}$ & 12 & 0.25 & $50 \pm 31$ \\
\hline $\mathbf{7}$ & 27 & 0.57 & $193 \pm 131$ \\
\hline $\mathbf{8}$ & 87 & 1.85 & $84 \pm 47$ \\
\hline $\mathbf{9}$ & 7 & 0.15 & $27 \pm 11$ \\
\hline $\mathbf{1 0}$ & 6 & 0.13 & $63 \pm 25$ \\
\hline
\end{tabular}

* $0=$ normal, 1= bloody milk, 2=coagulated milk, 3=mastitis, 4=inguinal and mammillitis $5=$ surgical cut, $6=$ traumatic inflammation and abrasions, $7=$ chronic clinical mastitis, 8=coagulated milk and teat paralysis, 9=teat claw and 10=purulent in udder.

\section{Relationship between UDQI and SCC}

Least squares constants for SCC as affected by UDQI classes are given in Table 5 . It could be noticed that SCC in milk increase with increasing number of infected quarters. Least squares constant of SCC for all udder quarters infections ( $7^{\text {th }}$ class, $5.54 \%$ of observations) was +157000 $\mathrm{cell} / \mathrm{ml}$, meanwhile the normal udders (0 class, uninfected) the least squares constant was $-488000 \mathrm{cell} / \mathrm{ml}$ (Table 5). Modransky and Welker (1993) found that the likelihood of cows developing mastitis is $50 \%$ higher in injured than in non-injured cows. Similar results were found by Pyorala et al. (1992) and Geishauser et al. (1999). Teat injury has been associated with high SCC in dairy cattle (Jorstad et al., 1989). Several studies have indicated a positive relationship between milk SCC and udder disease (Coffey et al., 1986a; Coffey et al., 1986b; Emanuelson, 1988; Emanuelson et al., 1988; Shook, 1989; Weller et al., 1992). Wilson et al. (1971) reported that in dual-purpose cows means for log SCC were lower for front than for rear quarters, although differences between left front and left rear quarters were not significant. 
Table 5: least squares constant \pm standard error (SE) for SCC $(1000 / \mathrm{ml})$ as affected by udder quarter infection classes (UDQI)

\begin{tabular}{|l|c|c|c|}
\hline \multirow{2}{*}{ Effect } & \multicolumn{2}{|c|}{ Observation } & SCC (x10 $/ \mathbf{m l})$ \\
\cline { 2 - 4 } & No. & $\%$ & Constant estimates \pm SE \\
\hline Constant & 4752 & 100 & $652 \pm 289$ \\
\hline UDQI classes $^{*}$ & & & $-488 \pm 146$ \\
\hline $\mathbf{0}$ & 4045 & 85.1 & $27 \pm 10$ \\
\hline $\mathbf{1}$ & 40 & 0.84 & $30 \pm 14$ \\
\hline $\mathbf{3}$ & 45 & 0.94 & $39 \pm 23$ \\
\hline $\mathbf{4}$ & 96 & 2.02 & $47 \pm 39$ \\
\hline $\mathbf{5}$ & 149 & 3.14 & $87 \pm 53$ \\
\hline $\mathbf{6}$ & 83 & 1.75 & $101 \pm 79$ \\
\hline $\mathbf{7}$ & 35 & 0.74 & $157 \pm 86$ \\
\hline
\end{tabular}

* $0=$ normal, $1=$ right fore quarter infection, $2=$ left fore quarter infection, $3=$ right hind quarter infection, 4= left hind quarter infection, 5= two quarters infection, $6=$ three quarters infections and $7=$ all quarters infections.

\section{Economic losses}

Losses in milk yield

Monthly and lactationally 305-dMY losses and losses in Egyptian pound (EGP) by SCC classes are presented in Table 6 . From this table, it is clear that milk yield losses $(\mathrm{kg})$ increase with increasing SCC and consequently decreasing in profitability. No losses in milk with less than $50,000 \mathrm{cell} / \mathrm{ml}$ ( $6.13 \%$ of observations). 17.3 of observation had 200,000 cell $/ \mathrm{ml}$ or less associated with $9 \mathrm{~kg}$ losses in milk per lactation/cow. The highest percentage of observations (20.7\%) had more than 200,000 to $300,000 \mathrm{cell} / \mathrm{ml}$ (4th class) with 17 and $135 \mathrm{~kg}$ losses equal 3.5 and 85.75 EGP of monthly and lactationally milk yield, respectively. Increasing SCC from more than 300,000 to $600,000 \mathrm{cell} / \mathrm{ml}$ (classes 5-7 SCC) increased monthly milk yield losses from 24 to $36 \mathrm{~kg}$ equal 42.0 to 63.0 EGP and lactationally losses in milk yield from 186 to $263 \mathrm{~kg}$ equal 325 to 460 EGP. Reduced milk production from cows with subclinical mastitis was responsible for the largest losses. Hagnestam-Nielsena and Østergaarda (2009) found that the cost (expressed per cow-year) per case of CM was estimated at $€ 428$. Estimates of the cost per case of CM vary depending on sources of economic loss included, data and estimation method, and can therefore not be easily compared. A partial explanation for this variation could be the milk yield of the cow during lactation. Emanuelson and Funke (1991) and Miller et al. (1993) found a "dilution effect" due to an inverse relationship between milk yield and milk SCC. Miller et al. (1993) suggested that the observed negative relationship between milk yield and SCC may partly reflect both the true biological effects of udder inflammation and a dilution effect. King (1972) cited a Milk Marketing Board study in Great Britain in 1971 which attributed losses of $164,289,661$, and $770 \mathrm{~kg}$ of milk/cow per year to SCC ranges of 250,000 to 499,$000 ; 500,000$ to 749,$000 ; 750,000$ to 999,000 ; and $1,000,000$ and over/ml. 
Table 6: Effect of SCC on losses monthly and lactationally milk yield (kg) and total returns (EGP)/ lactation/ cow

\begin{tabular}{|c|c|c|c|c|c|c|}
\hline \multirow{2}{*}{$\begin{array}{l}\text { SCC Classes } \\
\left(x 10^{3} / \mathrm{ml}\right)\end{array}$} & \multicolumn{2}{|c|}{ Observations } & \multicolumn{2}{|c|}{ Milk yield losses/cow } & \multicolumn{2}{|c|}{ Losses by EGP/cow } \\
\hline & No. & $\%$ & Monthly & Lactation & monthly & lactationlly \\
\hline$\leq 50$ & 289 & 6.13 & - & - & - & - \\
\hline$>50-100$ & 527 & 11.2 & - & $-9 \pm 03$ & - & $15.8 \pm 5.25$ \\
\hline$>100-200$ & 497 & 10.6 & $-2.0 \pm 0.91$ & $-49 \pm 19$ & $3.50 \pm 1.59$ & $85.8 \pm 33.3$ \\
\hline$>200-300$ & 977 & 20.7 & $-17 \pm 3$ & $-135 \pm 47$ & $29.8 \pm 5.25$ & $236 \pm 82.3$ \\
\hline$>300-400$ & 424 & 9.00 & $-24 \pm 4$ & $-186 \pm 53$ & $42.0 \pm 7.00$ & $325 \pm 92.8$ \\
\hline$>400-500$ & 319 & 6.77 & $-32 \pm 4$ & $-250 \pm 89$ & $56.0 \pm 7.00$ & $437 \pm 155$ \\
\hline$>500-600$ & 312 & 6.62 & $-36 \pm 6$ & $-263 \pm 96$ & $63.0 \pm 10.5$ & $460 \pm 168$ \\
\hline$>600-700$ & 326 & 6.92 & $-40 \pm 6$ & $-318 \pm 103$ & $70.0 \pm 10.5$ & $556 \pm 180$ \\
\hline$>700-800$ & 390 & 8.28 & $-47 \pm 9$ & $-374 \pm 109$ & $82.3 \pm 15.8$ & $655 \pm 190$ \\
\hline$>800-1000$ & 249 & 5.28 & $-51 \pm 11$ & $-563 \pm 123$ & $89.3 \pm 19.3$ & $985 \pm 215$ \\
\hline$>1000-2000$ & 217 & 4.61 & $-73 \pm 14$ & $-749 \pm 139$ & $128 \pm 24.5$ & $1311 \pm 243$ \\
\hline$>2000$ & 185 & 3.93 & $-93 \pm 18$ & $-991 \pm 161$ & $163 \pm 31.5$ & $1734 \pm 281$ \\
\hline
\end{tabular}

EGP = Egyptian pound

\section{Losses in fat and protein yields}

Monthly and lactationally 305-dFY and 305-dPY losses and losses in Egyptian pound (EGP) by SCC classes are presented in Table 7. From this table, it is clear that both FY and PY $(\mathrm{kg})$ increase with increasing SCC. No losses in fat and protein yields with less than $100,000 \mathrm{cell} / \mathrm{ml}(11.2 \%$ of observations). 17.3 of observation had $200000 \mathrm{cell} / \mathrm{ml}$ or less associated with 2.1 and $1.02 \mathrm{~kg}$ losses in fat and protein yields per lactation/cow, respectively. Losses in monthly and lactationally fat and protein yields increase with increasing SCC. The highest percentage of animals $(20.7 \%)$ which had 200,000 to $300,000 \mathrm{cell} / \mathrm{ml}$ with fat yield losses 0.34 and $3.69 \mathrm{~kg}$ per month and lactation, respectively. The corresponding figures for protein yield were 0.16 and $1.87 \mathrm{~kg}$, respectively (Table 7 ).

Table 7: Effect of SCC on losses monthly and lactationally fat (FY) and protein (PY) yields per cow

\begin{tabular}{|c|c|c|c|c|c|c|}
\hline \multirow{2}{*}{$\begin{array}{l}\text { SCC }\left(x 10^{3}\right. \\
\text { cell } / \mathrm{ml})\end{array}$} & \multicolumn{2}{|c|}{ Observation } & \multicolumn{2}{|c|}{ Losses/month/cow } & \multicolumn{2}{|c|}{ Losses/lactation/cow } \\
\hline & No. & $\%$ & FY (kg) & PY (kg) & FY (kg) & PY (kg) \\
\hline$\leq 50$ & 289 & 6.13 & - & - & - & - \\
\hline$>50-100$ & 527 & 11.2 & - & - & - & - \\
\hline$>100-200$ & 497 & 10.6 & $-0.02 \pm 00$ & $-0.01 \pm 00$ & $-2.01 \pm 2$ & $-1.02 \pm 1$ \\
\hline$>200-300$ & 977 & 20.7 & $-0.34 \pm 00$ & $-0.16 \pm 0.02$ & $-3.69 \pm 2$ & $-1.87 \pm 1$ \\
\hline$>300-400$ & 424 & 9.00 & $-0.42 \pm 0.03$ & $-0.19 \pm 0.02$ & $-4.76 \pm 3$ & $-2.14 \pm 3$ \\
\hline$>400-500$ & 319 & 6.77 & $-0.57 \pm 0.03$ & $-0.32 \pm 0.02$ & $-5.79 \pm 3$ & $-3.44 \pm 4$ \\
\hline$>500-600$ & 312 & 6.62 & $-0.66 \pm 0.03$ & $-0.52 \pm 0.02$ & $-6.24 \pm 3$ & $-4.93 \pm 4$ \\
\hline$>600-700$ & 326 & 6.92 & $-1.11 \pm 0.10$ & $-0.63 \pm 0.04$ & $-9.97 \pm 5$ & $-6.43 \pm 4$ \\
\hline$>700-800$ & 390 & 8.28 & $-1.35 \pm 0.12$ & $-0.94 \pm 0.11$ & $-12.2 \pm 6$ & $-9.67 \pm 4$ \\
\hline$>800-1000$ & 249 & 5.28 & $-1.99 \pm 0.12$ & $-1.13 \pm 0.11$ & $-17.7 \pm 6$ & $-12.9 \pm 6$ \\
\hline$>1000-2000$ & 217 & 4.61 & $-2.16 \pm 0.17$ & $-1.69 \pm 0.14$ & $-22.8 \pm 6$ & $-16.9 \pm 6$ \\
\hline$>2000$ & 185 & 3.93 & $-3.01 \pm 0.17$ & $-2.12 \pm 0.14$ & $-27.9 \pm 6$ & $-21.0 \pm 6$ \\
\hline
\end{tabular}

Dohoo and Meek (1982) stated that, in dairy cattle, high cell count milk has lower fat and lactose levels than low cell count milk. On the other hand, Eicher et al. (1999) found that SCC did not influence protein in milk from dairy cows. Schultz (1977) compared milk production for full lactations 
of cows whose milk gave varying reactions to monthly test by the Filter-DNA method. He found that cows whose milk averaged less than 500,000 somatic cells $/ \mathrm{ml}$ produced $572 \mathrm{~kg}$ more milk and $25 \mathrm{~kg}$ more fat per lactation than cows whose average lactation SCC was more than $1 \mathrm{million} / \mathrm{ml}$.

\section{Relationship between SCC and daily milk yield and daily losses returns}

Relationship between SCC classes, percent quarters infected, daily milk losses and daily losses returns (EGP)/ cow is given in Table 8. Daily milk yield losses increased with increasing SCC. No milk losses in cows with $50,000 \mathrm{cell} / \mathrm{ml}$ or less. Daily milk losses ranged between $0.21 \mathrm{~kg}$ for cows with 100,000 to 200,000 to $16.4 \mathrm{~kg}$ for cows with more than $2000,000 \mathrm{cell} / \mathrm{ml}$ ( 0.368 to $28.8 \mathrm{EGP}$ ). From Table 8 , it could be noticed also that number of quarter infected increase with increasing SCC. Several studies (e.g. Dohoo and Meek, 1982 and Schepers et al., 1997) reported that the most important factor affecting the SCC of the milk from an individual quarter, and consequently the cow and the herd, is the infection status of the quarter. In a review of mastitis literature, Janzen (1970) cited losses of milk per quarter per day in mastitic cows of 0.34 to $2.66 \mathrm{~kg}(9.0$ to $43.3 \%)$. De Graafa, and Dwingerb (1996) working with dairy cattle in Costa Rica and found that crude milk production losses per cow with sub-clinical mastitis were estimated at $1.56 \mathrm{~kg} /$ day for daily milk yield. Milk production loss per affected quarter due to sub-clinical mastitis was estimated to be $17.6 \%$ on average. No significant difference in milk production loss was detected when the data were stratified on the number of quarters affected.

Table 8: Relationship between SCC classes, percent quarters infected, daily milk losses $(\mathrm{kg})$ and daily losses returns (EGP)/ cow

\begin{tabular}{|c|c|c|c|c|}
\hline \multirow{2}{*}{$\begin{array}{l}\text { SCC (1000/ml) } \\
\text { Classes }\end{array}$} & \multicolumn{2}{|c|}{ Quarters infected } & \multirow{2}{*}{$\begin{array}{c}\text { Daily milk } \\
\text { Losses/cow }\end{array}$} & \multirow{2}{*}{$\begin{array}{l}\text { Daily losses } \\
\text { (EGP/cow) }\end{array}$} \\
\hline & No. & $\%$ & & \\
\hline$\leq \mathbf{5 0}$ & - & & - & - \\
\hline$>50-100$ & 24 & 2.70 & - & - \\
\hline$>100-200$ & 30 & 3.37 & 0.21 & 0.37 \\
\hline$>200-300$ & 49 & 5.51 & 0.50 & 0.88 \\
\hline$>300-400$ & 59 & 6.64 & 0.97 & 1.70 \\
\hline$>400-500$ & 70 & 7.87 & 2.29 & 4.01 \\
\hline$>500-600$ & 71 & 7.99 & 3.03 & 5.30 \\
\hline$>600-700$ & 72 & 8.10 & 3.42 & 6.00 \\
\hline$>700-800$ & 82 & 9.22 & 5.50 & 9.63 \\
\hline$>800-1000$ & 106 & 11.9 & 7.30 & 12.8 \\
\hline$>1000-2000$ & 120 & 13.5 & 12.0 & 21.0 \\
\hline$>2000$ & 206 & 23.2 & 16.4 & 28.8 \\
\hline
\end{tabular}

EGP = Egyptian pound

\section{Genetic parameters}

Table 9 shows genetic and phenotypic variances and covariances and Table 10 shows heritability estimates and genetic and phenotypic correlations for different traits under investigation.

\section{Heritabilities}

Heritability estimates $( \pm S E)$ of udder health and milk production traits are given in Table 10. Heritability estimates of 305-dMY, 305-dFY and 305- 
dPY were $0.31 \pm 0.04,0.33 \pm 0.03$ and $0.35 \pm 0.05$, respectively. The high heritability of these traits point out to the possibility of genetic improvement through genetic selection. Meanwhile, the heritability estimates of udder health traits ranged between low to moderate $(0.23 \pm 0.02,0.14 \pm 0.02,0.13$ \pm 0.03 and $0.09 \pm 0.01$ for SCC, MAST, UDHS and UDQI, respectively). Lund et al. (1994) using first lactation data from the Danish young sire sampling program found that heritabilities were low for mastitis $(0.025)$, SCC $(0.18)$ and other diseases $(0.011)$.

Table 9: Estimates of (co)variance components for different traits studied.

\begin{tabular}{|c|c|c|c|c|c|c|c|c|c|c|c|c|c|c|}
\hline \multirow[t]{2}{*}{ Trait } & \multicolumn{7}{|c|}{ Genetic variance (bold) and covariance } & \multicolumn{7}{|c|}{ Phenotypic variance (bold) and covariance } \\
\hline & MY & FY & PY & SCC & MAST & UDHS & UDQ & MY & FY & PY & SCC & MAST & UDHS & UDQ \\
\hline MY & 12219.9 & & & & & & & 39215.7 & & & & & & \\
\hline FY & 3627.9 & 2483.9 & & & & & & 9816.8 & 7489.6 & & & & & \\
\hline$P Y$ & 3719.4 & 1323.9 & 1891.4 & & & & & 8459.9 & 5151.6 & 5374.2 & & & & \\
\hline SCC & -3112.8 & -1030.7 & -976.2 & 2584.3 & & & & -12491.6 & -4512.3 & -5078.2 & 18123.8 & & & \\
\hline MAST & -87.9 & -41.1 & -38.9 & 53.9 & 1.55 & & & -247.9 & -65.1 & -51.1 & 241.8 & 6.71 & & \\
\hline UDHS & -130.2 & -60.9 & -47.3 & 70.1 & 1.80 & 2.50 & & -341.9 & -91.1 & -99.2 & 428.9 & 9.4 & 19.55 & \\
\hline USQI & -16.8 & -5.3 & -5.1 & 8.8 & 0.23 & 0.31 & 0.05 & -77.1 & -15.9 & -22.8 & 52.8 & 1.5 & 2.93 & 0.55 \\
\hline
\end{tabular}

Table 10: Estimates of heritability ( \pm SE on diagonal), genetic (above diagonal) and phenotypic (below diagonal) correlations and SE (between parentheses) among different studied traits.

\begin{tabular}{|l|c|c|c|c|c|c|c|}
\hline Trait & $\mathbf{3 0 5 - d M Y}$ & $\mathbf{3 0 5}-\mathbf{d F Y}$ & $\mathbf{3 0 5 - d P Y}$ & $\mathbf{S C C}$ & MAST & UDHS & UDQI \\
\hline $\mathbf{3 0 5 - d M Y}$ & $\mathbf{0 . 3 1} \mathbf{0 . 0 4}$ & $0.66(0.06)$ & $0.77(0.07)$ & $-0.55(0.05)$ & $-0.64(0.07)$ & $-0.74(0.06)$ & $-0.68(0.05)$ \\
\hline $\mathbf{3 0 5 - d F Y}$ & 0.57 & $\mathbf{0 . 3 3} \mathbf{0 . 0 3}$ & $0.61(0.05)$ & $-0.41(0.04)$ & $-0.66(0.06)$ & $-0.77(0.09)$ & $-0.48(0.04)$ \\
\hline $\mathbf{3 0 5 - d P Y}$ & 0.58 & 0.81 & $\mathbf{0 . 3 5} \mathbf{0 . 0 5}$ & $-0.44(0.05)$ & $-0.72(0.07)$ & $-0.69(0.10)$ & $-0.52(0.06)$ \\
\hline SCC & -0.47 & -0.39 & -0.51 & $\mathbf{0 . 2 3} \mathbf{0 . 0 2}$ & $0.85(0.08)$ & $0.87(0.11)$ & $0.77(0.07)$ \\
\hline MAST & -0.48 & -0.29 & -0.27 & 0.69 & $\mathbf{0 . 1 4} \pm \mathbf{0 . 0 2}$ & $0.91(0.11)$ & $0.83(0.09)$ \\
\hline UDHS & -0.39 & -0.24 & -0.31 & 0.72 & 0.82 & $\mathbf{0 . 1 3} \pm \mathbf{0 . 0 3}$ & $0.88(0.09)$ \\
\hline USQI & -0.52 & -0.25 & -0.42 & 0.53 & 0.78 & 0.89 & $\mathbf{0 . 0 9} \mathbf{0 . 0 1}$ \\
\hline
\end{tabular}

\section{Correlations}

Genetic and phenotypic correlations among different studied traits are given in Table 10. From this table it could be noticed that all milk production traits showed slightly unfavorable negative phenotypic and genetic correlations with SCC, MAST and UDQI. There were positive and high genetic correlations between SCC and each of MAST (0.85), UDHS (0.87) and UDQI (0.77) and between MAST and each of UDHS (0.91) and UDQI (0.83). The values of phenotypic correlations between udder health traits and milk production traits followed the same trend of the values of genetic correlations. The genetic correlation between 305-dMY and each of 305-dFY and 305-dPY were positive and high (0.57). 305-dMY positively and highly genetic correlated with each of $305-\mathrm{dFY}(0.66 \pm 0.06)$ and $305-\mathrm{dPY}(0.77 \pm$ $0.07)$, and also between $305-\mathrm{dFY}$ and $305-\mathrm{dPY}(0.61 \pm 0.05)$.

Regarding correlations among other udder health traits and milk production traits, the statistical analyses in this study confirmed the unfavourable genetic relationship between milk production and udder health traits. Generally, genetic and phenotypic covariances between udder health and milk production traits were negative. These negative covariances yielded 
negative genetic and phenotypic correlations between udder health and milk production traits. High negative genetic correlations were found between udder health traits and each of 305-dMY (ranged between -0.55 to -0.74), $305-\mathrm{dFY}$ (ranged between -0.41 to -0.77 ) and 305-dPY (ranged between 0.44 to -0.72 ). In the same trend, there were also high and negative phenotypic correlations between udder health traits and each of 305-dMY (ranged between -0.39 to -0.52 ), 305-dFY (ranged between -0.24 to -0.29 ) and 305-dPY (ranged between -0.27 to -0.51 ) (Table 10). Estimates of genetic correlations between clinical mastitis and milk production traits vary in the literature. In general, correlations between clinical mastitis and production traits have been unfavorable (e.g., Hansen et al., 2002; Carlén et al., 2004; Negussie et al., 2006). Schepers et al. (1997) found that the shape of the SCC curve was inversely related to the shape of the milk production curve.

Table 10 shows also that there were very high positive genetic correlations between SCC and each of MAST $(0.85 \pm 0.08)$, UDHS $(0.87 \pm 0.11)$ and UDQI $(0.77 \pm 0.07)$. The corresponding figures for the phenotypic correlations were $0.69,0.72$ and 0.53 , for the same traits, respectively. The genetic correlation between MAST and each of UDHS and UDQI were $0.91 \pm 0.11$ and $0.83 \pm 0.01$ and between UDHS and UDQI was $0.88 \pm 0.09$ (Table 10). The present study confirmed the genetic antagonism between production and health. This unfavorable genetic association between production and health was also confirmed in other comprehensive field studies where the following genetic correlations between clinical mastitis and yield were found to be 0.51 by Simianer et al. (1991), •,$\{7$, by Pösö and Mäntysaari, (1996), 0.31 to 0.49 by Luttinen and Juga (1997), 0.43 by Lund et al. (1999), 0.25 by Heringstad et al. (1999), and 0.15 to 0.41 by Rupp and Boichard (1999). Nielsen et al. (1997) found a genetic correlation between clinical mastitis and protein yield of 0.34 . On the other hand, negative correlations have also been reported $(-0.40)$ (Pryce et al., 1997). It recommended that if direct information on under health traits is not available, measures of SCC can be used indirectly to improve these traits genetically. Lund et al (1994) found that the estimate of the genetic correlation between SCC and clinical mastitis was high at 0.97 and the genetic correlation between clinical mastitis and other diseases was moderately high at 0.53 . Schepers et al. (1997) found that the effect of clinical mastitis on SCC was significant.

\section{CONCLUSION}

From the results in this paper it could be concluded that economic losses from mastitis and high SCC are considerable. Heritability estimate for mastitis is low (0.14). There is an unfavorable genetic correlation between udder health and milk production traits, and this emphasizes the need to include mastitis resistance in the breeding goal. Accuracy of selection can be increased by combining information on MAST and SCC, which are rather strongly genetically correlated $(0.85)$. The high genetic correlation between SCC and clinical mastitis makes SCC a feasible indicator for clinical mastitis. So, somatic cell count, should be included in the economic breeding index for 
udder health. It recommended also that if direct information on under health traits is not available, measures of SCC can be used indirectly to improve these traits genetically.

\section{ACKNOWLEDGMENTS}

The authors gratefully acknowledge Animal Production Research Institute, Ministry of Agriculture, Egypt for making the data available, and Prof. Dale Van Vleck, Department of Animal Science, University of Nebraska, Lincoln, USA for providing the MTDFREML software and its documents.

\section{REFERENCES}

Barkema, H.W., Schukken, Y.H., Lam, T.J.G.M, Beiboer, M.L., Wilmink, H., Benedictus, G. and Brand, A. (1998). Incidence of clinical mastitis in dairy herds grouped in three categories by bulk milk somatic cell counts. J. Dairy Sci., 81: 411-419.

Bartlett, P. C., Anderson, C. R. and J. H. Kirk. (1990). Milk production and somatic cell count in Michigan dairy herds. J. Dairy Sci., 73: 27942800.

Blosser, T. H. (1979). Economic Losses from and the National Research Program on Mastitis in the United States. J. Dairy Sci., 62: 119-127.

Boldman, K.G.; Kriese, L.A.; Van Vleck, L.D. and Van Tassel, C.P. (1995). A manual for the use of MTDFREML. A set of programs to obtain estimates of variance and covariances (Draft). USDA, Agricultural Research Service.

Carlén, E., Strandberg, E. and Roth, A. (2004). Genetic parameters for clinical mastitis, somatic cell score, and production in the first three lactations of Swedish Holstein cows. J. Dairy Sci., 87, 3062-3070.

Coffey, E.M., Vinson, W.E. and Pearson, R.E. (1986a). Somatic cell counts and infection rates for cows of varying somatic cell count in initial test of first lactation. J. Dairy Sci., 69: 552-555.

Coffey, E.M., Vinson, W.E. and Pearson, R.E. (1986b). Potential of somatic cell concentration in milk as a sire selection criterion to reduce mastitis in dairy cattle. J. Dairy Sci., 69: 2163-2172.

De Graafa, D. and Dwingerb, R. H. (1996). Estimation of milk production losses due to sub-clinical mastitis in dairy cattle in Costa Rica. Prev. Vet. Med., 26 (3-4): 215-222.

De Graves, F.J. and Fetrow, J. (1993). Economics of mastitis and mastitis control. Vet. Clin. N. Am., Food Anim. Prog. 9: 421-434.

Dohoo, I.R. and Leslie, K.E. (1991). Evaluation of changes in somatic cell counts as indicators of new intramammary infections. Preventive Veterinary Medicine 10:225-237.

Dohoo, I.R. and Meek A.H. (1982). Somatic cell counts in bovine milk. Can. Vet. J., 23: 119-125.

Dürr, J.W. Cue R.I. Monardes H.G. Moro-Méndez J. and Wade K.M. (2008). Milk losses associated with somatic cell counts per breed, parity and stage of lactation in Canadian dairy cattle. Livestock Science, 117: 225-232 
Eicher, R., Bouchard, E. and Bigras-Poulin, M. (1999). Factors affecting milk urea nitrogen and protein concentrations in Quebec dairy cows. Prev. Vet. Med., 39: 53-63.

El-Arian, M.N. and El-Awady, H.G. (2008). Assessment of the genetic relationships between udder health and milk production traits in relation to selection for improving resistance to mastitis in Friesian cows in Egypt. J. Agric. Sci., Mansoura Univ., 33:181-192.

Emanuelson, U. (1988). Recording of production diseases in cattle and possibilities for genetic improvements: a review. Livest. Prod. Sci., 20: 89-106.

Emanuelson U., Danell B. and Philipsson J. (1988). Genetic parameters for clinical mastiffs, somatic cell counts, and milk production estimated by Multiple-Trait Restricted Maximum Likelihood. J Dairy Sci., 71:467476.

Emanuelson, U. and Funke, H. (1991). Effect of milk yield on relationship between bulk milk somatic cell count and prevalence of mastitis, $\mathrm{J}$. Dairy Sci.. 74: 2479-2483.

Geishauser, T., Querengasser, K., Nitschke, M. and Sorbiraj, A. (1999). Milk yield, somatic cell counts, and risk of removal from the herd for dairy cows after covered teat canal injury. J. Dairy Sci., 82: 1482-1488.

Hagnestam, C., Emanuelson, U. and Berglund, B. (2007). Yield losses associated with clinical mastitis occurring in different weeks of lactation. J. Dairy Sci., 90: 2260-2270.

Hagnestam-Nielsena, C. and Østergaarda, S. (2009). Economic impact of clinical mastitis in a dairy herd assessed by stochastic simulation using different methods to model yield losses. Animal, 3:315-328.

Hansen, M., M. S. Lund, M. K. Sørensen, and L. G. Christensen (2002). Genetic Parameters of Dairy Character, Protein Yield, Clinical Mastitis, and Other Diseases in the Danish Holstein Cattle. J. Dairy Sci., 85:445-452.

Harvey, W.R. (1990). User's Guide For LSMLMW, Mixed Model Least Squares Program. PC-2 Version. Ohio State. University, Columbus (Mimeograph), USA.

Heringstad B, Klemetsdal G, Ruane J (1999) Clinical mastitis in Norwegian cattle: Frequency, variance components, and genetic correlation with protein yield. J Dairy Sci., 82: 1325-1330.

Heringstad, B., Klemetsdal, G. and Ruane, J. (2000). Selection for mastitis resistance in dairy cattle: a review with focus on the situation in the Nordic countries. Livest. Prod. Sci., 64: 95-106.

Hultgren, J. and Svensson, C .(2009). Lifetime risk and cost of clinical mastitis in dairy cows in relation to heifer rearing conditions in southwest Sweden. J. Dairy Sci., 92: 3274-3280.

Interbull (2008). Description of national genetic evaluation systems for dairy cattle traits as applied in different Interbull member countries. Retrieved September 4, $2008 \quad$ from http://wwwinterbull.slu.se/national ges info2/framesida-ges.htm.

Jackson, P. (1996). Skin diseases of the bovine udder and teat. In Pract., 18: 76-80. 
Janzen, J. J. (1970). Economic losses resulting from mastitis. A review. J. Dairy Sci., 53:1151.

Jorstad, A., Farver, T.B. and Riemann, H. (1989). Teat canal diameter and other cow factors with possible influence on somatic cell counts in cow milk. Acta Vet. Scand., 30: 239-245.

King, J. O. L. (1972). Mastitis as a production disease. Vet. Rec. 91:325.

Laevens, H., Deluyker, H., Schukken, Y.H., De Meulemeester, L., Vandermeersch, R., De Muelenaere, E. and De Kruif, A. (1997). Influence of parity and stage of lactation on the somatic cell count in bacteriologically negative dairy cows. J. Dairy Sci., 80: 3219-3226.

Lassen, J. M. Hansen, M.K. Sørensen, G.P. Aamand, Christensen, L.G. and Madsen, P. (2003). Genetic relationship between body condition score, dairy character, mastitis, and diseases other than mastitis in first-parity Danish Holstein cows. J. Dairy Sci. 86:3730-3735.

Losinger W.C. (2005). Economic impacts of reduced milk production associated with an increase in bulk-tank somatic cell count on US dairies. J. Am Vet Med Assoc., 226 (10): 1652-1658.

Lund, M. S., Jensen, J. and Peterson, P. H. (1999). Estimation of genetic and phenotypic parameters for clinical mastitis, somatic cell production deviance, and protein yield in dairy cattle using Gibbs sampling. J. Dairy Sci., 82:1045-1051.

Lund, T., Miglior, F., Dekkers, J. C. M. and Burnside, E. B. (1994). Genetic relationships between clinical mastitis, somatic cell count, and udder conformation in Danish Holsteins. Livest. Prod. Sci., 39(3): 243-251.

Luttinen, A., and Juga, J. (1997). Genetic relationships between milk yield, somatic cell count, mastitis, milkability and leakage in Finnish dairy cattle. Interbull Bull. 15:78-83.

Miglior, F.; Muir, B.L. and van Doormaal, B.J. (2005). Selection indices in Holstein cattle of various countries. J. Dairy Sci., 88:1255-1263.

Miller, R. H., Paape, M. J. Filep, R. and Link, S. (1993). Flow cytometric analysis of neutrophils in cows' milk. Am. J. Vet. Res., 54:1975-1979.

Modransky, P. and Welker, B. (1993). Management of teat lacerations and fistulae in cows. Vet. Med., 88: 995-1000.

Mrode, R. A., and Swanson, G. J. T. (1996). Genetic and statistical properties of somatic cell count and its suitability as an indirect means of reducing the incidence of mastitis in dairy cattle. Anim. Breed. Abstr., 66:847857.

Negussie, E., Koivula, M. and Mäntysaari, E. A.(2006). Genetic parameters and single versus multi-trait evaluation of udder health traits. Acta Agriculturae Scandinavica, Section A - Animal Sciences 56: 73-82.

Nielsen, U. S., Pedersen, G. A. and Jensen, J. (1997). Genetic correlations among health traits in different lactations. Interbull Bull., 15: 68-77.

Nooruddin, M., Rahman, M.S. and Rahman, M.M. (1997). Prevalence and distribution of teat papillomatosis in crossbred and exotic dairy cows. Bangladesh Vet., 14(1-2): 5-7.

Nyman, A.K. (2007). Epidemiological studies of risk factors for bovine mastitis. Doctoral thesis. Swedish University of Agricultural Sciences. Uppsala, Sweden. 
O'Rourke, D. (2009). Nutrition and udder health in dairy cows: A review. Irish Vet. J., 62 (supplement): 15-22.

Petzer, I-M., Karzis, J., Watermeyer, J.C., Van der Schans, T.J., \& Van Reenen, R. (2009). 'Trends in udder health and emerging mastitogenic pathogens in South African dairy herds', Journal of the South African Veterinary Association, Vol. 80, no. 1, pp. 17-22. [http://www.journals.co.za/ej/ejour_savet.html].

Philipsson, J., Ral, G. and Berglund, B. (1995). Somatic cell count as a selection criteria for mastitis resistance in dairy cattle. Livest. Prod. Sci., 41: 195-200.

Pösö, J. and Mäntysaari, E.A. (1996). Relationships between clinical mastitis, somatic cell score, and production for the first three lactations of Finnish Ayrshire. J. Dairy Sci., 79:1284-1291.

Pryce, J.E., Veerkamp, R.F., Esslemont, R.J., Kossaibati, M.A., Simm, G. (1997). Genetic associations amongst health and fertility traits for two UK recording schemes. Interbull bulletin, 15:92-97.

Pyorala, S., Somer, H.J. and Mero, M. (1992). Clinical, bacteriological and therapeutic aspects of bovine mastitis caused by aerobic and anaerobic pathogens. Br. Vet. J., 148: 54-62.

Rupp, R. and Boichard, D. (1999). Genetic parameters for clinical mastitis, somatic cell score, production, udder type traits, and milking ease in first lactation Holsteins. J. Dairy Sci., 82: 2198-2204.

Schepers, A.J., Lam, T.J.G.M., Schukken, Y.H., Wilmink, J.B.M. and Hanekamp, W.J.A., (1997). Estimation of variance components for somatic cell counts to determine thresholds for uninfected quarters. J. Dairy Sci., 80: 1833-1840.

Schepers, J.A. and A.A. Dijkhuizen (1991). The economics of mastitis and mastitis control in dairy cattle: A critical analysis of estimates published since 1970. Prev. Vet. Med., 10: 213-224.

Schukken, Y.H., Grommers, F.J, Van de Geer, D., Erb, H.N. and Brand, A. (1990). Risk factors for clinical mastitis in herds with a low bulk milk somatic cell count. 1. Data and risk factors for all cases. J. Dairy Sci., 73: 3463-3471.

Schultz, L. H. (1977). Somatic cells in milk - physiological aspects and relationship to amount and composition of milk. J. Food Prot. 40:125.

Seegers, H., Fourichon, C. and Beaudeau, F. (2003). Production effects related to mastitis and mastitis economics in dairy cattle herds. Vet. Res., 34: 475-491.

Shook, G.E. (1989). Selection for disease resistance. J. Dairy Sci., 72: 13491362.

Simianer, H., Solbu, H. and Schaeffer, L. R. (1991). Estimated genetic correlations between disease and yield traits in dairy cattle. J. Dairy Sci., 74: 4359-4365.

Weller, J.I., Saran, A. and Zeliger, Y. (1992). Genetic and environmental relationships among somatic cell count, bacterial infection, and clinical mastitis. J. Dairy Sci., 75: 2532-2540. 
White, J.M. and Vinson, W.E. (1975). Relationships among Udder Characteristics, Milk Yield, and Non-yield Traits. J Dairy Sci., 58: 729738.

Wilson, L.L., Eberhart, R.J., Simpson, M.J., Varela-Alvarez, H., Rugh, M.C. and Bair, L.G., (1971). Incidence of intramammary infections and effects of number of lactations, lactation stage, quarter and calf sex on somatic cell content of milk from Angus-Holstein F1 cows. J. Anim. Sci., 33: 433-437.

تحليل وراثى واقتصادي للعلاقة بين صفات صحة الضرع وصفات إنتاج اللبن فى أبقار الفريزيان

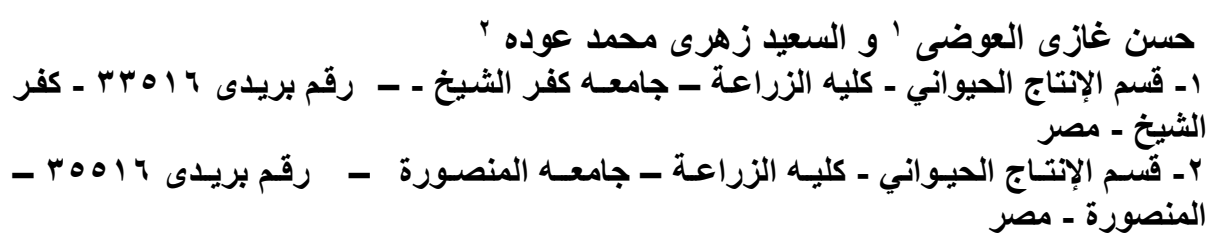

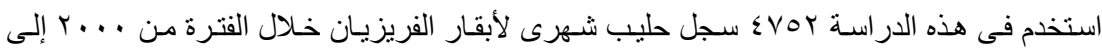

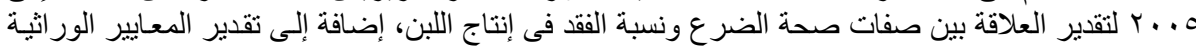

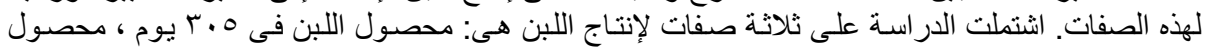

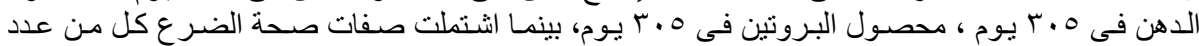

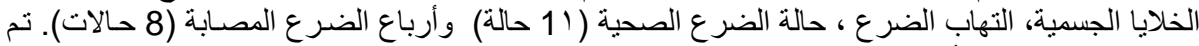

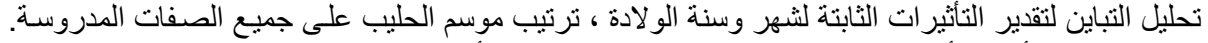

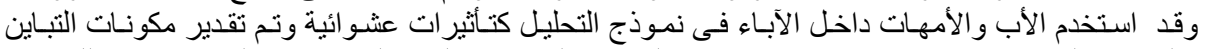

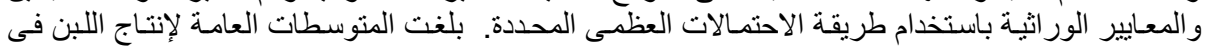

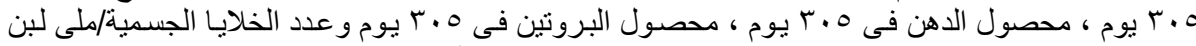

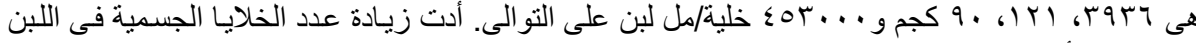

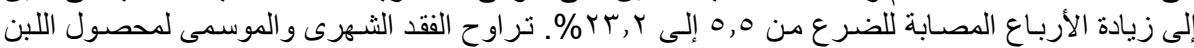

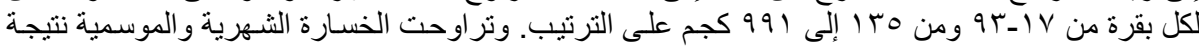

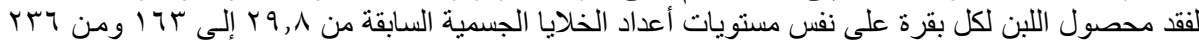

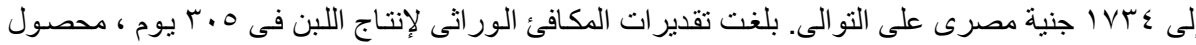

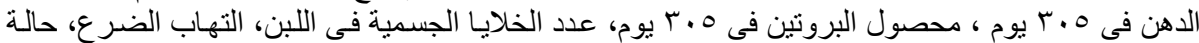

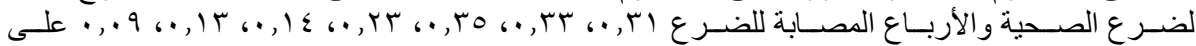

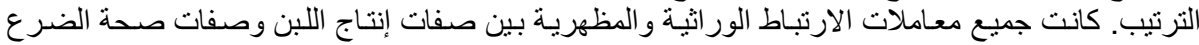

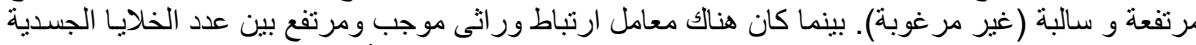

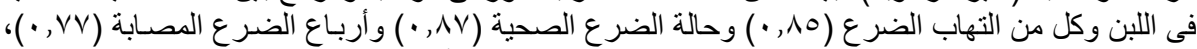

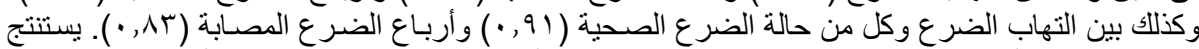

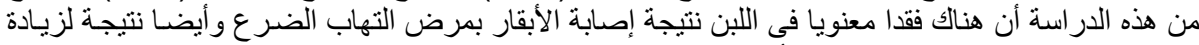

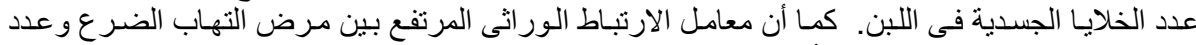

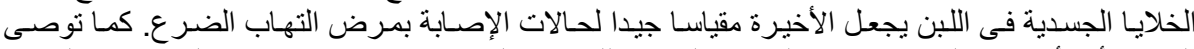

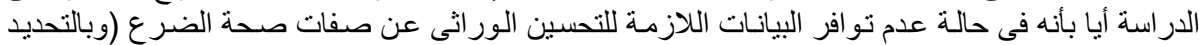

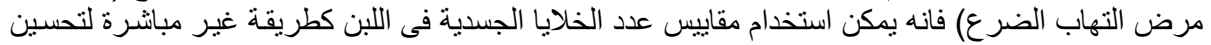

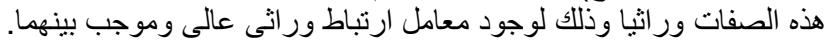

